\title{
Right place, right time: localisation and assembly of the
}

\section{NLRP3 inflammasome [version 1; peer review: 3 approved]}

\author{
Claire Hamilton, Paras K. Anand (iD)
}

Infectious Diseases and Immunity, Department of Medicine, Imperial College London, The Commonwealth Building, Du Cane Road, London, W12 0NN, UK

V1 First published: 17 May 2019, 8(F1000 Faculty Rev):676

https://doi.org/10.12688/f1000research.18557.1

Latest published: 17 May 2019, 8(F1000 Faculty Rev):676

https://doi.org/10.12688/f1000research.18557.1

\section{Abstract}

The NLRP3 inflammasome is a multimeric protein complex that cleaves caspase-1 and the pro-inflammatory cytokines interleukin 1 beta (IL-1 $\beta$ ) and IL-18. Dysregulated NLRP3 inflammasome signalling is linked to several chronic inflammatory and autoimmune conditions; thus, understanding the activation mechanisms of the NLRP3 inflammasome is essential. Studies over the past few years have implicated vital roles for distinct intracellular organelles in both the localisation and assembly of the NLRP3 inflammasome. However, conflicting reports exist. Prior to its activation, NLRP3 has been shown to be resident in the endoplasmic reticulum (ER) and cytosol, although, upon activation, the NLRP3 inflammasome has been shown to assemble in the cytosol, mitochondria, and mitochondriaassociated ER membranes by different reports. Finally, very recent work has suggested that NLRP3 may be localised on or adjacent to the Golgi apparatus and that release of mediators from this organelle may contribute to inflammasome assembly. Therefore, NLRP3 may be strategically placed on or in close proximity to these subcellular compartments to both sense danger signals originating from these organelles and use the compartment as a scaffold to assemble the complex. Understanding where and when NLRP3 inflammasome assembly occurs may help identify potential targets for treatment of NLRP3-related disorders.

\section{Keywords}

NLRP3, caspase-1, mitochondria, endoplasmic reticulum, Golgi, inflammasome, IL-1 $\beta$, IL-18, cholesterol, SREBP2

\section{Open Peer Review}

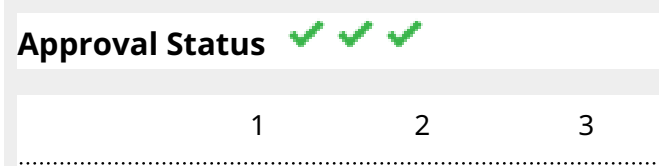

\section{version 1}

17 May 2019

Faculty Reviews are review articles written by the prestigious Members of Faculty Opinions. The articles are commissioned and peer reviewed before publication to ensure that the final, published version is comprehensive and accessible. The reviewers who approved the final version are listed with their names and affiliations.

1. Rongbin Zhou, University of Science and

Technology of China, Hefei, China

2. Je-Wook Yu, Yonsei University College of Medicine, Seoul, South Korea

3. Masafumi Takahashi, Jichi Medical University, Tochigi, Japan

Any comments on the article can be found at the end of the article. 
Corresponding author: Paras K. Anand (paras.anand@imperial.ac.uk)

Author roles: Hamilton C: Conceptualization, Visualization, Writing - Original Draft Preparation, Writing - Review \& Editing; Anand PK: Conceptualization, Funding Acquisition, Supervision, Visualization, Writing - Original Draft Preparation, Writing - Review \& Editing

Competing interests: No competing interests were disclosed.

Grant information: Research in the laboratory of PA is supported by funds from the Wellcome Trust (108248/Z/15/Z), the Medical Research Council (MR/S00968X/1), and core funds from Imperial College London.

The funders had no role in study design, data collection and analysis, decision to publish, or preparation of the manuscript.

Copyright: @ 2019 Hamilton C and Anand PK. This is an open access article distributed under the terms of the Creative Commons Attribution License, which permits unrestricted use, distribution, and reproduction in any medium, provided the original work is properly cited.

How to cite this article: Hamilton C and Anand PK. Right place, right time: localisation and assembly of the NLRP3 inflammasome [version 1; peer review: 3 approved] F1000Research 2019, 8(F1000 Faculty Rev):676 https://doi.org/10.12688/f1000research.18557.1

First published: 17 May 2019, 8(F1000 Faculty Rev):676 https://doi.org/10.12688/f1000research.18557.1 


\section{Introduction}

Inflammasomes are multimeric protein complexes composed of typically a Nod-like receptor (NLR) or absent in myeloma 2 (AIM2), the adaptor molecule apoptosis-associated speck-like protein containing a CARD (ASC), and the effector protease caspase-1. Upon activation, the receptor dimerises and recruits ASC via pyrin domain interactions and ASC subsequently interacts with caspase- 1 via their respective CARD domains. Caspase-1 undergoes autoproteolytic cleavage to produce an active fragment which is able to cleave the precursor forms of cytokines interleukin 1 beta (IL-1 $\beta$ ) and IL-18, leading to pro-inflammatory responses ${ }^{1-5}$. In addition to cleaving the above cytokines, caspase-1 cleaves gasdermin-D (GSDMD) to produce an active N-terminal fragment which subsequently inserts into the plasma membrane and assembles a pore, resulting in an inflammatory cell death termed pyroptosis ${ }^{6-8}$.

Of all the NLR inflammasomes characterised to date, the NLRP3 inflammasome has been the most extensively studied, largely due to its role in several infectious and inflammatory disorders ${ }^{9-14}$. Activation of the NLRP3 inflammasome is unique in that it requires two signals to assemble. The first signal involves ligation of typically a Toll-like receptor (TLR), initiating activation of the transcription factor nuclear factor kappa-lightchain-enhancer of activated B cells $(\mathrm{NF}-\mathrm{\kappa B})$ and upregulation of pro-IL-1 $\beta$ and NLRP3. This initial step is often referred to as the "priming" signal. The second signal (also known as the activating signal) is induced by a wide variety of substances, including exogenous and endogenous compounds such as ATP, silica, cholesterol crystals, and alum, as well as a variety of bacterial, viral and fungal pathogens or their toxins (or both). How such a wide variety of structurally and chemically diverse entities are all able to activate the NLRP3 inflammasome has been at the forefront of inflammasome biology for the last decade. It is commonly accepted that all of these ligands do not bind NLRP3 directly and instead converge on a cellular pathway which subsequently activates NLRP $3^{15}$. Mechanisms proposed for NLRP3 activation include $\mathrm{K}^{+}$efflux, mitochondrial dysfunction, production of reactive oxygen species (ROS), lysosomal rupture, and $\mathrm{Ca}^{2+}$ mobilisation. Although some of these mechanisms are involved in response to many NLRP3 activators, absolute requirement of any specific mechanism with all activating signals is still to be demonstrated, thereby precluding a consensus on the central NLRP3 inflammasome-activating mechanism. A common theme among many of the proposed mechanisms is the sensing of molecules released as a result of cellular/ organelle stress and dysfunction ${ }^{16-18}$. Additionally, emerging evidence has now suggested key homeostatic functions for endoplasmic reticulum (ER) and Golgi in NLRP3 activation ${ }^{18-22}$. Here, we review recent literature focusing on the roles that mitochondria, ER, and Golgi play in the localisation, assembly, and activation of the NLRP3 inflammasome. Though less studied, the requirement of these organelles in activation of other inflammasomes, when relevant, is also discussed. A critical role for lysosomes has been recognised in response to particulate ligands; however, we have not included a separate section on this organelle as it has been discussed in detail in several published reviews ${ }^{23-25}$.

\section{Cellular localisation of NLRP3 and ASC}

Studies conducted almost a decade ago suggested NLRP3 inflammasome localisation on mitochondria and mitochondriaassociated ER membranes $(\mathrm{MAMs})^{26}$. Detailed biochemical studies demonstrated that, under resting conditions, the majority of NLRP3 is located in the ER and cytosol of THP-1 cells overexpressing NLRP3. However, upon activation with NLRP3 activators monosodium urate (MSU) or nigericin, NLRP3 relocated to the perinuclear space and associated with both mitochondrial and ER markers and therefore is thought to be located on MAMs, composed of both ER and mitochondrial outer membrane fragments ${ }^{26}$. A small fraction of NLRP3 was also found in the cytosol upon activation. Similarly, Yang et al. have demonstrated that the activated NLRP3 inflammasome is located on the mitochondria ${ }^{27}$. Conversely, Wang et al. showed that the NLRP3 inflammasome shows no association with mitochondrial markers and was located solely in the cytosol of mouse macrophages exposed to lipopolysaccharide (LPS) and $\mathrm{ATP}^{28}$. However, the location of NLRP3 may be cell-specific, as nuclear localisation was reported in $\mathrm{CD}^{+}{ }^{+} \mathrm{Th} 2$ cells, whereas cytoplasmic location was observed in $\mathrm{CD}^{+} \mathrm{Th} 1$ cells following differentiation ${ }^{29}$. In this case, nuclear NLRP3 transcriptionally regulated $\mathrm{Th} 2$ differentiation of $\mathrm{CD}^{+} \mathrm{T}$ cells but did not participate in inflammasome formation per $\mathrm{se}^{29}$.

The recruitment of NLRP3 to MAMs may be dependent on mitochondrial cardiolipin or the presence of mitochondrial antiviral signalling (MAVS), an outer mitochondrial membrane protein involved in retinoic acid-inducible gene I (RIG-I)mediated interferon (IFN) responses ${ }^{30-32}$. Additionally, the translocation of NLRP3 to mitochondria may rely on the presence of a short sequence in the N-terminal domain of human NLRP ${ }^{30}$; although murine NLRP3 differs in this minimal N-terminal sequence, it too was found to be associated with mitochondria upon activation $^{32}$. Other studies found a role for microtubules in the transport of NLRP3 to mitochondria and this was aided by microtubule-affinity regulating kinase 4 (MARK4), which helped position NLRP3 to mitochondria for effective "speck" formation and optimal inflammasome activity (Figure 1). mCherry-tagged NLRP3 was shown to move along microtubules towards mitochondria in nigericin-activated THP-1 cells, a response that was diminished in MARK4 knock-down cells ${ }^{33}$. In agreement, inhibition of tubulin polymerisation by either colchicine or nocodazole diminished NLRP3 inflammasome activation ${ }^{33,34}$. The localisation of NLRP3 on or in close vicinity to mitochondria offers an obvious advantage to the cell as any disturbance in cellular homeostasis leading to mitochondrial dysfunction would result in efficient sensing and activation of NLRP3. Studies on the localisation of ASC within the cell are somewhat contradictory; Misawa et al. demonstrated the localisation in the mitochondria, cytosol, and nucleus under resting conditions in primary bone marrow-derived macrophages $(\mathrm{BMDMs})^{34}$. Once an activating signal is sensed, a dynein-dependent mechanism transports ASC on the mitochondria in close proximity to NLRP3 on the ER ${ }^{34}$. This transport was shown to be independent of $\mathrm{K}^{+}$efflux and mitochondrial ROS (mtROS). Additionally, other reports have shown ASC to reside exclusively in the cytosol and in the nucleus under resting conditions and to associate 


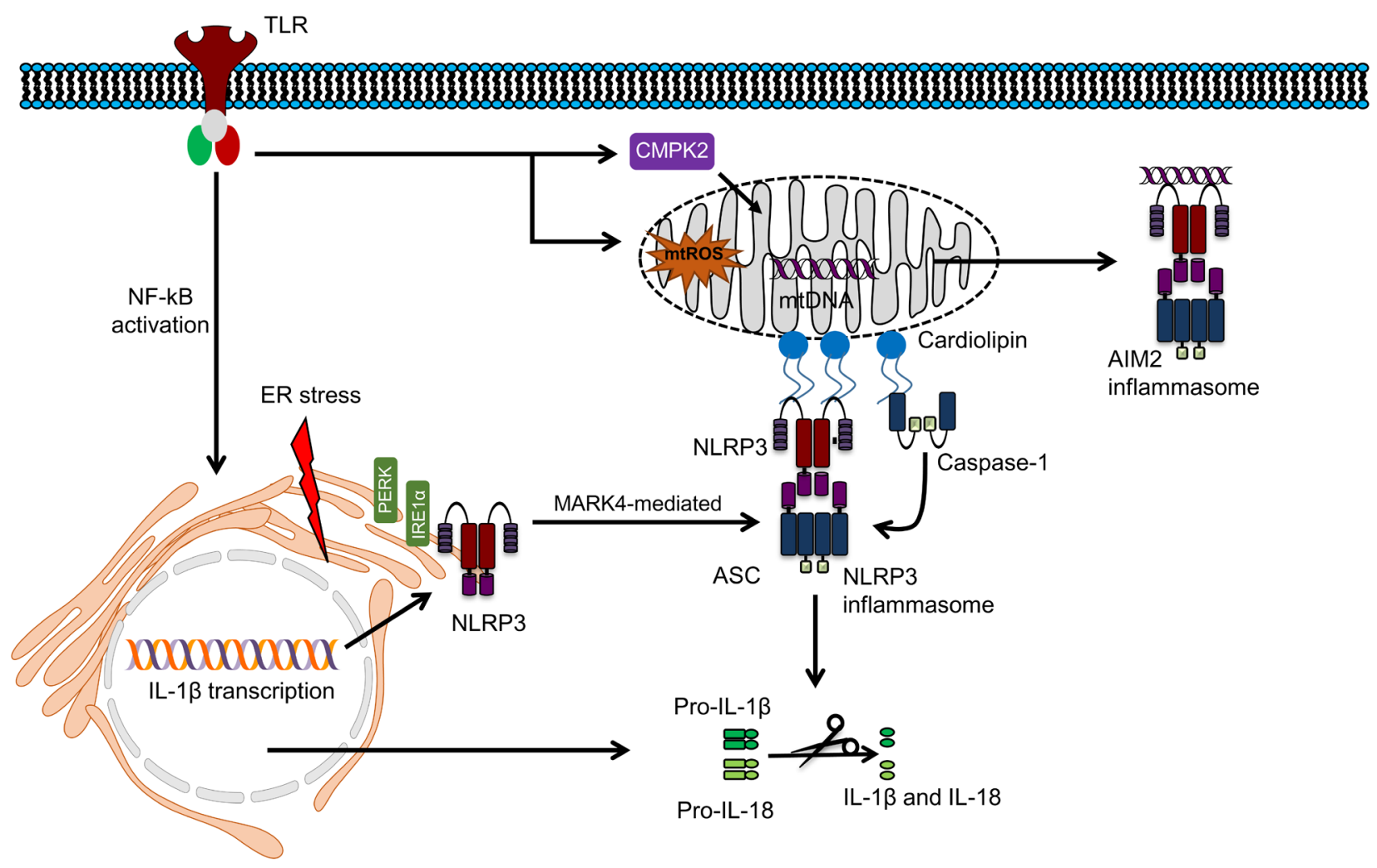

Figure 1. Mitochondria and ER in activation of the NLRP3 inflammasome. A proportion of NLRP3 has been shown to reside in the ER prior to activation and translocate to the mitochondria or mitochondria-associated membranes during activation. The translocation of NLRP3 to the mitochondria has been shown to be dependent on microtubule rearrangement and microtubule kinase MARK4. Activation of the NLRP3 inflammasome requires two signals. The first signal, referred to as NLRP3 "priming", requires activation of NF-kB (for example, through TLR stimulation) and the upregulation of NLRP3 and IL-13. The second activating signal has been shown to be mediated via several mechanisms. TLR priming induced upregulation of mtDNA via CMPK2, and the upregulation of mtROS has been shown to activate the NLRP3 at the mitochondria. mtDNA may also be able to activate the AIM2 inflammasome. ER stress has also been implicated in NLRP3 inflammasome activation, and ER stress-induced activation of the UPR response pathway, including UPR sensors IRE1 $\alpha$ and PERK, is required for NLRP3 inflammasome activation. Following activation, the NLRP3 inflammasome leads to the activation of caspase-1 and subsequent cleavage of $\mathrm{IL}-1 \beta$ and IL-18. AIM2, absent in myeloma 2; ASC, apoptosis-associated speck-like protein containing a CARD; CMPK2, cytidine/uridine monophosphate kinase 2; ER, endoplasmic reticulum; IL-1 $\beta$, interleukin-1 beta; IL-18, interleukin-18; IRE1 $\alpha$, inositol-requiring protein 1 alpha; MARK4, microtubule-affinity regulating kinase 4; mtDNA, mitochondrial DNA; mtROS, mitochondrial reactive oxygen species; NF- $\mathrm{KB}$, nuclear factor kappa-light-chain-enhancer of activated B cells; PERK, protein kinase R-like endoplasmic reticulum kinase; TLR, Toll-like receptor; UPR, unfolded protein response.

with mitochondria upon NLRP3 inflammasome activation ${ }^{26,35}$. Whether the nature of the upstream stimuli calibrates the localisation of the NLRP3 inflammasome to distinct subcellular compartments is still unclear, as is the localisation of other inflammasome-forming receptors.

\section{Mitochondria}

Mitochondrial dysfunction leads to NLRP3 inflammasome activation

Positioning of NLRP3 following activation on MAMs/mitochondria is thought to enable immediate recognition of mitochondrial damage, which has been proposed as a central event downstream of various NLRP3-activating stimuli. These damage signals include mtROS, mitochondrial DNA (mtDNA) and cardiolipin (Figure 1) $26,36,37$.

Cellular ROS was initially shown to activate the NLRP3 inflammasome in an NAPDH-dependent manner; however, further studies showed that ROS generated by the mitochondria is sufficient to lead to NLRP3 activation ${ }^{26,38,39}$. Specific inhibition of mtROS significantly diminishes NLRP3 inflammasome activation $^{40}$. Yu et al. demonstrated that mitochondrial damage following NLRP3 inflammasome activation occurs in a caspase1 -dependent manner, resulting in the release of $\mathrm{mtROS}^{41}$. Caspase- 1 was demonstrated to amplify this response by inhibiting mitophagy, the process of removal of damaged mitochondria, which then contributed to pyroptosis induction ${ }^{41}$. Conversely, ROS production has been shown to be dispensable for NLRP3 inflammasome activation, and the significance of $\mathrm{K}^{+}$efflux has been highlighted $^{42}$, thereby suggesting these as independent NLRP3 activation mechanisms. How increases in mtROS production activate NLRP3 is still unclear, although TXNIP has been implicated by various studies ${ }^{43-45}$. TXNIP is a negative regulator of the antioxidant thioredoxin (TRX) and is thought to dissociate from TRX in the presence of ROS, allowing TXNIP to bind to NLRP3. In agreement, NLRP3 inflammasome activation is impaired in 
TXNIP $^{-/}$mice $^{46}$. The precise mechanism remains unresolved. Furthermore, mutations in mtDNA-encoded cytochrome $b$ gene in patients with fibromyalgia are associated with mitochondrial dysfunction and increased ROS production, leading to enhanced caspase-1 cleavage, and IL-1 $\beta$ and IL-18 secretion in fibroblasts and serum respectively ${ }^{47}$. Increases in ROS have previously been implicated in other inflammatory disorders ${ }^{48,49}$.

In addition to mtROS, the release of mtDNA - in particular, oxidised mtDNA-in response to mitochondrial dysfunction activates the NLRP3 inflammasome ${ }^{36,50,51}$. NLRP3 inflammasome priming via TLRs has been shown to induce mtROS production and, more recently, the production of $\mathrm{mtDNA}^{52,53}$. The latter is dependent on MyD88/TRIF- and IRF-1-mediated upregulation of mitochondrial deoxyribonucleotide kinase, CMPK2, an enzyme with rate-limiting activity in mtDNA synthesis ${ }^{53}$. The newly synthesised mtDNA (made during priming) was found to be necessary to generate oxidised mtDNA fragments when cells were subsequently exposed to an NLRP3-activating signal (Figure 1) $)^{53}$. Of note, oxidised DNA from any cellular source can activate the NLRP3 inflammasome. In fact, mtDNA contributes to inflammation in diseases such as atherosclerosis and inflammatory kidney disorders, and the inhibition of its release by exposure to agents that maintain mitochondrial integrity prevents NLRP3 inflammasome activation ${ }^{54-59}$. Contrary to the above, TLR-dependent priming also restricts inflammasome activation through efficient removal of damaged mitochondria. TLR-activated NF- $\mathrm{KB}$ pathway induces prolonged accumulation of the autophagic receptor p62/SQSTM1, which targets damaged mitochondria for clearance by mitophagy ${ }^{60}$, thereby preventing NLRP3 over-activation ${ }^{61}$. Whether inhibition of mtDNA release or maintenance of mitochondrial integrity (or both) will translate into novel therapeutics for disorders in which NLRP3 inflammasome is dysregulated is yet to be seen.

A small number of studies have implicated mtDNA in the activation of other inflammasome complexes. Mitochondrial damage by Pseudomonas aeruginosa leads to the release of ROS and mtDNA; the latter was shown to bind and activate the NLRC4 inflammasome. In agreement, abolition of mtDNA by DNase I treatment resulted in reduced caspase-1 activation and IL-1 $\beta$ secretion following $P$. aeruginosa infection ${ }^{62}$. However, caspase-1 activation was not completely abolished by DNase I in $\mathrm{NlrC4}^{-/-}$macrophages, suggesting roles for other inflammasomes, and the authors attributed this to AIM2 inflammasome activation. Although NLRP3 is not thought to be involved during $P$. aeruginosa infection, a role for NLRP3 was not experimentally ruled out ${ }^{62,63}$. Dang et al. also demonstrated that mtDNA, released as a result of loss of mitochondrial integrity by elevated cellular cholesterol levels, can activate the AIM2 inflammasome in macrophages lacking cholesterol-25-hydroxylase. In wild-type cells, production of 25-hydroxycholesterol (25-HC) by cholesterol-25-hydroxylase repressed cholesterol biosynthesis, thereby maintaining mitochondrial integrity ${ }^{64}$. However, only a small redundant role for NLRP3 was found in the above study, although mtDNA is known to activate this inflammasome ${ }^{36}$. As the AIM2 inflammasome can recognise both foreign and self-DNA, it is likely that it can also recognise mtDNA; however, further studies are required to confirm these findings. Whether mtDNA has the ability to directly activate multiple inflammasomes ${ }^{65}$ or whether upstream stimuli direct differential activation of NLRP3 and AIM2 inflammasomes requires further clarification.

NLRP3 is recruited to and binds mitochondrial cardiolipin Cardiolipin, a phospholipid localised to the inner mitochondrial membrane (IMM), has also been linked to NLRP3 inflammasome activation. Upon NLRP3 activation or in the presence of stimuli that destabilise mitochondria, cardiolipin redistributes to the outer leaflet of the mitochondrial membrane (OMM), where NLRP3 anchors through its leucine-rich repeat (LRR) domain $^{37,66}$ (Figure 1). Depletion of cardiolipin or abrogation of cardiolipin synthesis by culturing cells in the presence of palmitate (C16:0), a saturated long-chain fatty acid, blunted inflammasome activation in J774A.1 macrophages ${ }^{37}$. Similarly, small interfering RNA (siRNA) knock-down of cardiolipin synthase reduced NLRP3 activation ${ }^{37}$. Corroborating these findings, activation of the NLRP3 inflammasome, by HIV reverse transcriptase inhibitor abacavir, was abrogated following inhibition of cardiolipin synthase- $1^{37}$. Furthermore, cardiolipin-dependent NLRP3 inflammasome activation by the antibiotic linezolid, which induces mitochondrial toxicity, was ROS-independent ${ }^{37}$. Thus, mitochondrial dysfunction, which induces ROS under certain conditions, and not ROS itself, may be responsible for NLRP3 inflammasome activation. Additionally, recent work from the group established that NLRP3 is recruited to the mitochondria at the priming stage and binds to cardiolipin on the $\mathrm{OMM}^{67}$. Interestingly, the movement of cardiolipin to the OMM was found to be dependent on ROS produced during the NLRP3 priming step. Surprisingly, caspase-1 also binds cardiolipin at the mitochondria, while ASC was recruited only following NLRP3 activation ${ }^{67}$. The binding of both caspase-1 and NLRP3 to mitochondrial cardiolipin validates mitochondria as a scaffold for inflammasome activation, thereby amplifying its activation by bringing molecules together (Figure 1). In line with this, other immune signalling pathways initiated at the mitochondria, including the MAVS complex, occur in a similar manner ${ }^{68}$. Additionally, these studies identify a role for priming beyond the upregulation of NLRP3 and pro-IL-1 $\beta$.

\section{Endoplasmic reticulum}

Endoplasmic reticulum stress triggers caspase-1 activation NLRP3 has been shown to reside in the ER prior to its activation, and ER dysfunction has been reported to trigger inflammasome activation (Figure 1). The ER is a membrane-bound organelle that is critical for protein folding, assembly and modification in addition to being the site for lipid synthesis and $\mathrm{Ca}^{2+}$ homeostasis. Cellular stress leading to accumulation of misfolded or unfolded proteins induces an unfolded protein response (UPR) aimed at restoring ER homeostasis by regulating levels of transcription, translation, and protein folding ${ }^{69}$. The UPR response activates several stress sensors located in the ER, including inositol-requiring protein 1 alpha (IRE1 $\alpha$ ), protein kinase R-like endoplasmic reticulum kinase (PERK), and activating transcription factor 6 (ATF6). These sensors subsequently regulate downstream cytosolic effectors and signalling pathways, including proteasomal degradation, autophagy, and antioxidant defence mechanisms. Prolonged ER stress induces an inflammatory response and cell damage, thereby triggering NLRP3 inflammasome activation ${ }^{18,70-73}$. An initial study suggested that 
ER stress activated the NLRP3 inflammasome via a UPRindependent pathway, as short hairpin RNA (shRNA) knockdown of either Irel $\alpha$ or Perk or macrophages obtained from Atf6 $\alpha^{-1}$ mice released comparable IL-1 $\beta$ following NLRP3 activation $^{74}$. However, the authors also noted that not all NLRP3 activators induced ER stress, indicating that this may be just one mechanism by which the NLRP3 inflammasome is activated. In agreement, Bronner et al. found that ER stress and IRE1 $\alpha$ were not induced in mouse BMDMs with the canonical NLRP3 activator ATP, although they were induced during Brucella abortus infection ${ }^{18}$. During $B$. abortus infection, IRE1 $\alpha$-initiated mtROS production recruited NLRP3 to mitochondria. Mechanistically, IRE1 $\alpha$ activated TXNIP and caspase-2, leading to truncation and activation of the mitochondrial protein Bid, which resulted in mitochondrial damage and release of mitochondrial damage-associated molecular patterns (DAMPs) that promoted NLRP3 activation ${ }^{18}$. Surprisingly, NLRP3 was required to activate caspase-2/Bid upstream of mitochondrial damage, suggesting a role for NLRP3 in initiating mitochondrial damage by a feedforward loop. IRE1 $\alpha$ and its activation of TXNIP have been implicated in NLRP3 inflammasome activation in other studies ${ }^{19,75-78}$. Similarly, inhibition of the ER stress sensor PERK was shown to reduce caspase- 1 activation and IL-1 $\beta$ secretion in J744.1 macrophages, although how PERK inhibition decreases NLRP3 activation was not determined ${ }^{79}$. Targeting IRE1 $\alpha$ to dampen ER stress-induced NLRP3 inflammasome activation has shown benefits in a wide variety of inflammatory conditions ${ }^{75,76,80-85}$. These studies again suggest mitochondrial damage as the downstream mechanism by which ER stress initiates NLRP3 inflammasome formation. Additionally, this work may indicate that the ER is the site where NLRP3 activation is initiated before the inflammasome is assembled in the cytosol or at the mitochondria/MAMs.

In addition to being implicated in the activation of the NLRP3 inflammasome, ER stress is thought to play a role in the activation of the NLRP1 inflammasome. NLRP1 expression in HeLa cells is upregulated upon induction of ER stress by tunicamycin and thapsigargin, which inhibit the N-linked glycosylation of proteins and sarcoplasmic/endoplasmic reticulum $\mathrm{Ca}^{2+}$-ATPase (SERCA) respectively. Upregulation of Nlrpl involved IRE1 $\alpha$ and PERK, and siRNA knock-down of either Ire $1 \alpha$ or Perk abrogated increase in NLRP1 expression ${ }^{86}$. Consistent with this, studies have shown a link between ER stress and NLRP1 upregulation in leukaemia and cardiovascular injury models ${ }^{87,88}$. Thus, as suggested by studies discussed below, ER seems to be a key subcellular site to regulate inflammasome activation.

\section{Endoplasmic reticulum calcium homeostasis in} inflammasome activation

The ER is also the site at which $\mathrm{Ca}^{2+}$ homeostasis occurs, and $\mathrm{Ca}^{2+}$ mobilisation has been implicated in NLRP3 inflammasome activation. Blockade of the ER-resident calcium channel IP3R led to reduced NLRP3 inflammasome activation in mouse macrophages ${ }^{89,90}$. Other studies have challenged these claims, showing no role for $\mathrm{Ca}^{2+}$ and indicating that $\mathrm{K}^{+}$efflux is more important ${ }^{42,91}$. It can be expected that, as with other mechanisms of NLRP3 activation, $\mathrm{Ca}^{2+}$ mobilisation from the ER activates the NLRP3 inflammasomes only under specific conditions.
Similarly, it is possible that $\mathrm{Ca}^{2+}$ mobilisation precedes ER stress or is a consequence of ER dysfunction and therefore happens to occur alongside ER stress-induced NLRP3 activation.

\section{Endoplasmic reticulum cholesterol levels regulate NLRP3 activation}

The ER not only is involved in lipid synthesis but also is the site at which cholesterol levels within the cell are sensed and regulated. Cellular cholesterol homeostasis is achieved by maintaining an equilibrium between de novo synthesis at the $\mathrm{ER}$, exogenous cholesterol uptake in the form of low-density lipoprotein (LDL), and cholesterol efflux programs. LDL is endocytosed by LDL receptor and subsequently trafficked through the endosomal system to other subcellular compartments, including the ER, plasma membrane, and Golgi. Blockade of cholesterol efflux from the lysosome was recently demonstrated to inhibit NLRP3 inflammasome activation in mouse macrophages, an effect attributed to decreased cholesterol within the $\mathrm{ER}^{21}$. Similarly, inhibition of cholesterol biosynthesis in the ER by exposing cells grown in lipoprotein-deficient media to statins dampened NLRP3 inflammasome activation ${ }^{21}$. Additionally, the ER-localised cholesterol-sensing transcription factor sterol regulatory element-binding protein 2 (SREBP2) has been implicated in NLRP3 inflammasome activation ${ }^{92}$. The cholesterol metabolite, 25-HC, has also been shown to activate the NLRP3 inflammasome by induction of $\mathrm{K}^{+}$efflux, mtROS production, and activation of the cholesterol transcriptional regulator liver $\mathrm{X}$ receptors (LXRs) ${ }^{93}$. Thus, either cholesterol may be involved in directly influencing inflammasome complex formation or ER cholesterol content may support NLRP3 in achieving the necessary conformation. Regardless, these studies emphasise a critical role for ER in inflammasome activation.

\section{The Golgi complex}

NLRP3 translocation near the Golgi is required for inflammasome activation

Although roles for mitochondria and ER have been suggested by many labs in the last decade, a few recent studies have also implicated Golgi in inflammasome activation. The Golgi apparatus is important for the modification and transport of proteins and lipids within the cell. Zhang et al. first implicated the Golgi in NLRP3 inflammasome activation. Following treatment with NLRP3 activators, the levels of diacyl glycerol (DAG) at the Golgi increased and this coincided with the localisation of NLRP3 on MAMs adjacent to the Golgi ${ }^{20}$. Disruption of Golgi integrity with brefeldin A reduced caspase-1 activation, IL-1 $\beta$ secretion and ASC speck formation following NLRP3 inflammasome activation, a result which was corroborated in a subsequent study ${ }^{94}$. This effect was attributed to protein kinase D (PKD), a DAG effector, which phosphorylated NLRP3 at a conserved residue (Ser293) in its NBD domain, allowing its release from MAMs to form an inflammasome complex within the cytosol (Figure 2). Of note, PKD phosphorylated after NLRP3 self-oligomerised and PKD inactivation both retained self-oligomerised NLRP3 at MAMs and reduced NLRP3 inflammasome activation. Interestingly, PKD inhibition in cells from patients with cryopyrin-associated periodic syndrome (who exhibit spontaneous NLRP3 oligomerisation) also showed reduced NLRP3 activation ${ }^{20}$. This added to previous studies that indicate that post-translational 


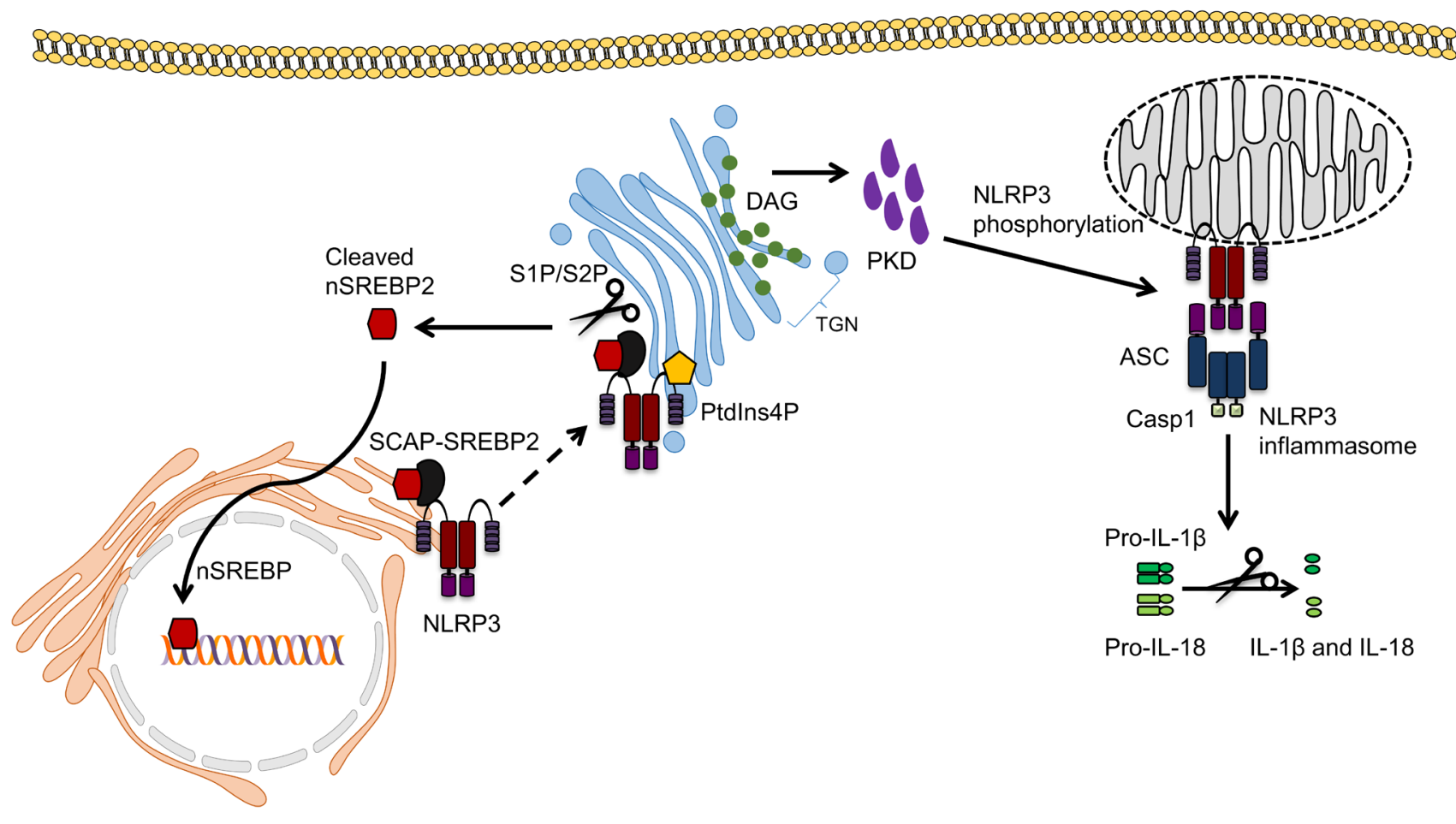

Figure 2. Emerging role of the Golgi apparatus in NLRP3 inflammasome activation. NLRP3 localised at the endoplasmic reticulum has been shown to translocate to the Golgi via binding to the SCAP-SREBP2 complex, which regulates cholesterol homeostasis. SREBP2 is cleaved at the Golgi by S1P and S2P to yield the active nuclear form of SREBP2, which then translocates to the nucleus and upregulates genes involved in cholesterol synthesis. NLRP3 has also been shown to be recruited to the TGN through ionic bonds formed with Ptdlns4P. The Golgi then acts as a scaffold for NLRP3 assembly. Finally, DAG accumulation at the Golgi recruits and activates PKD, which is required for NLRP3 phosphorylation at the mitochondria, leading to its release and activation at mitochondrial-associated membranes. ASC, apoptosisassociated speck-like protein containing a CARD; DAG, diacylglycerol; IL-1 3 , interleukin-1 beta; IL-18, interleukin-18; PKD, protein kinase D; PtdIns4p, phosphatidylinositol-4-phosphate; S1P, site-1 protease; S2P, site-2 protease; SREBP2, sterol regulatory element-binding protein 2; TGN, trans-Golgi network.

modifications can both positively and negatively affect NLRP3 activation $^{95,96}$. Furthermore, this study highlights cross-talk between Golgi and MAMs during NLRP3 inflammasome activation by means of DAG accumulation. In support of this, a recent study demonstrated recruitment of NLRP3 to the trans-Golgi network (TGN) through ionic bonding between NLRP3 and phosphatidylinositol-4-phosphate (PtdIns4P) in the membrane of the Golgi (Figure 2) ${ }^{22}$. The authors found that the TGN dispersed and formed vesicles in the perinuclear space that co-localised with overexpressed NLRP3 following inflammasome activation in HeLa cells. Similar results were shown in primary BMDMs lacking ASC; therefore, whether the full assembly of the inflammasome complex occurs at the TGN was not addressed. However, in that study, in contrast to previous studies, NLRP3 was not found to be associated with mitochondria, and instead the TGN, rather than the mitochondria, provided the scaffold for NLRP3 inflammasome activation ${ }^{22}$. Furthermore, translocation of NLRP3 from the ER to the Golgi, this time requiring SREBP and SREBP cleavage-activating protein (SCAP), has also been reported in primary mouse macrophages ${ }^{92}$. When cholesterol levels within the cell are low, the SCAP-SREBP2 complex translocates from the ER to the Golgi, where SREBP2 is cleaved into its active form by site-1 protease (S1P) and site-2 protease $(\mathrm{S} 2 \mathrm{P})$, and translocates to the nucleus to transcribe genes involved in cholesterol biosynthesis and uptake ${ }^{97}$. The latter study demonstrated that NLRP3 partially co-localises with SCAP-SREBP2 and translocates to the Golgi, and that inhibition of SCAP-SREBP2 translocation abrogated NLRP3 inflammasome activation (Figure 2). Subcellular fractionation studies showed NLRP3 in the Golgi as well as in the mitochondrial fraction with SCAP. This correlates with findings from Zhang et al., who suggested that NLRP3 activation occurs in close proximity to both the Golgi and the mitochondria ${ }^{20}$. Whether multiple mechanisms can independently initiate NLRP3 recruitment to the Golgi requires further work and so does the role of NLRP3 phosphorylation in inflammasome activation.

\section{Concluding remarks}

The intracellular milieu of the cell is vital for maintenance of cell function as well as the many cellular processes. Damage to organelles, caused by either endogenous agents or invading pathogens, has been demonstrated to activate NLRP3 inflammasome, leading to pro-inflammatory cytokine release and cell death via pyroptosis. Although a consensus has yet to be reached as to the precise location of the resting NLRP3 and the inflammasome complex, several studies have indicated that NLRP3 translocates to the mitochondria or MAMs following activation (Table 1). The mitochondria are integral to providing 
Table 1. Localisation of NLRP3 before and after NLRP3 inflammasome activation.

\begin{tabular}{|c|c|c|c|c|}
\hline & Cells and method employed & Resting NLRP3 & $\begin{array}{l}\text { Activated NLRP3/NLRP3 } \\
\text { inflammasome }\end{array}$ & Reference \\
\hline 1. & $\begin{array}{l}\text { THP-1 cells overexpressing FLAG-tagged NLRP3 } \\
\text { and ASC } \\
\text { Subcellular fractionation and confocal and } \\
\text { electron microscopy }\end{array}$ & ER and cytosol & MAMs & Zhou et al. ${ }^{26}$ (2011) \\
\hline 2. & $\begin{array}{l}\text { Peritoneal macrophages from C57BL/6 mice } \\
\text { Immunofluorescence microscopy }\end{array}$ & - & Cytosol & Wang et al. ${ }^{28}(2013)$ \\
\hline 3. & $\begin{array}{l}\text { HEK-293T overexpressing NLRP3 - Confocal } \\
\text { microscopy } \\
\text { Wild-type and } \text { Asc }^{-/-} \text {immortalised BMDMs } \\
\text { - Subcellular fractionation }\end{array}$ & Cytosol & Mitochondria & Subramanian et al. ${ }^{30}$ (2013) \\
\hline 4. & BMDMs - Immunofluorescence microscopy & ER & $\begin{array}{l}\text { Mitochondria/ER } \\
\text { (microtubules bring ASC on } \\
\text { mitochondria and NLRP3 on } \\
\text { ER together) }\end{array}$ & Misawa et al. ${ }^{34}$ (2013) \\
\hline 5. & $\begin{array}{l}\text { BMDMs - Subcellular fractionation and } \\
\text { immunofluorescence microscopy }\end{array}$ & - & Mitochondria & Yang et al. ${ }^{27}$ (2015) \\
\hline 6. & BMDMs and THP-1 cells - Confocal microscopy & Cytosol & MAMs $\rightarrow$ cytosol & Zhang et al. ${ }^{20}(2017)$ \\
\hline 7. & $\begin{array}{l}\text { HeLa cells overexpressing NLRP3 - Subcellular } \\
\text { fractionation and fluorescence microscopy } \\
\text { Asc-/- BMDMs - Immunofluorescence } \\
\text { microscopy }\end{array}$ & $\begin{array}{l}\text { Cytosol and trans- } \\
\text { Golgi network }\end{array}$ & Trans-Golgi network & Chen and Chen 22 (2018) \\
\hline
\end{tabular}

ASC, apoptosis-associated speck-like protein containing a CARD; BMDM, bone marrow-derived macrophage; ER, endoplasmic reticulum; MAM, mitochondria-associated endoplasmic reticulum membrane.

the cell with its source of energy; therefore, it is conceivable that any insult to this compartment is sufficient to be perceived as a danger signal. NLRP3 localisation on or in proximity to mitochondria upon activation supports the notion that it is competently positioned to sense danger signals originating from this organelle. This is backed by the numerous studies demonstrating an association between loss of mitochondrial integrity and NLRP3 inflammasome activation. The direct roles of other subcellular compartments in inflammasome assembly remain to be established, although studies have shown vital roles for ER stress signalling and ER cholesterol content in NLRP3 inflammasome activation. Unravelling the input of distinct organelles in NLRP3 inflammasome assembly will provide crucial insights into how cells sense and coordinate the activation of the NLRP3 inflammasome. This new understanding would enable the development of therapeutics that calibrate NLRP3 activation to maintain cellular homeostasis.

\section{Grant information}

Research in the laboratory of PA is supported by funds from the Wellcome Trust (108248/Z/15/Z), the Medical Research Council (MR/S00968X/1), and core funds from Imperial College London.

The funders had no role in study design, data collection and analysis, decision to publish, or preparation of the manuscript.

\section{Acknowledgements}

We apologise to the numerous investigators whose work could not be cited due to space limitations.
1. $\quad F$ Broz P, Dixit VM: Inflammasomes: mechanism of assembly, regulation and signalling. Nat Rev Immunol. 2016; 16(7): 407-20. PubMed Abstract | Publisher Full Text | F1000 Recommendation

2. Man SM, Kanneganti TD: Regulation of inflammasome activation. Immunol Rev. 2015; 265(1): 6-21.

PubMed Abstract | Publisher Full Text | Free Full Text

3. Mathur A, Hayward JA, Man SM: Molecular mechanisms of inflammasome signaling. J Leukoc Biol. 2018; 103(2): 233-257. PubMed Abstract | Publisher Full Text
4. Sharma D, Kanneganti TD: The cell biology of inflammasomes: Mechanisms of inflammasome activation and regulation. J Cell Biol. 2016; 213(6): 617-29. PubMed Abstract | Publisher Full Text | Free Full Text

5. Groslambert M, Py BF: Spotlight on the NLRP3 inflammasome pathway. J Inflamm Res. 2018; 11: 359-74. PubMed Abstract | Publisher Full Text | Free Full Text

6. Liu X, Zhang Z, Ruan J, et al:: Inflammasome-activated gasdermin D causes pyroptosis by forming membrane pores. Nature. 2016; 535(7610): 153-8. PubMed Abstract | Publisher Full Text | Free Full Text 
7. $\mathrm{F}$ Shi $\mathrm{J}$, Zhao $\mathrm{Y}$, Wang $\mathrm{K}$, et al.: Cleavage of GSDMD by inflammatory caspases determines pyroptotic cell death. Nature. 2015; 526(7575): 660-5. PubMed Abstract | Publisher Full Text | F1000 Recommendation

8. F Kayagaki N, Stowe IB, Lee BL, et al:: Caspase-11 cleaves gasdermin D for non-canonical inflammasome signalling. Nature. 2015; 526(7575): 666-71. PubMed Abstract | Publisher Full Text | F1000 Recommendation

9. Mangan MSJ, Olhava EJ, Roush WR, et al:: Targeting the NLRP3 inflammasome in inflammatory diseases. Nat Rev Drug Discov. 2018; 17(8): 588-606. PubMed Abstract | Publisher Full Text

10. Hamilton C, Tan L, Miethke T, et al.: Immunity to uropathogens: the emerging roles of inflammasomes. Nat Rev Urol. 2017; 14(5): 284-95. PubMed Abstract | Publisher Full Text

11. Lupfer $\mathrm{C}$, Anand PK: Integrating Inflammasome Signaling in Sexually Transmitted Infections. Trends Immunol. 2016; 37(10): 703-14. PubMed Abstract | Publisher Full Text | Free Full Text

12. Lupfer $\mathrm{CR}$, Anand PK, Liu Z, et al.: Reactive oxygen species regulate caspase-11 expression and activation of the non-canonical NLRP3 inflammasome during enteric pathogen infection. PLOS Pathog. 2014; 10(9): e1004410. PubMed Abstract | Publisher Full Text | Free Full Text

13. Gurung P, Malireddi RK, Anand PK, et al:: Toll or interleukin-1 receptor (TIR) domain-containing adaptor inducing interferon- $\beta$ (TRIF)-mediated caspase-11 protease production integrates Toll-like receptor 4 (TLR4) protein- and NIrp3 inflammasome-mediated host defense against enteropathogens. J Biol Chem. 2012; 287(41): 34474-83.

PubMed Abstract | Publisher Full Text | Free Full Text

14. Lukens JR, Kanneganti TD: Beyond canonical inflammasomes: emerging pathways in IL-1-mediated autoinflammatory disease. Semin Immunopathol. 2014; 36(5): 595-609.

PubMed Abstract | Publisher Full Text | Free Full Text

15. Anand PK, Malireddi RK, Kanneganti TD: Role of the nlrp3 inflammasome in microbial infection. Front Microbiol. 2011; 2: 12.

PubMed Abstract | Publisher Full Text | Free Full Text

16. Próchnicki T, Latz E: Inflammasomes on the Crossroads of Innate Immune Recognition and Metabolic Control. Cell Metab. 2017; 26(1): 71-93. PubMed Abstract | Publisher Full Text

17. Gurung $P$, Lukens JR, Kanneganti TD: Mitochondria: diversity in the regulation of the NLRP3 inflammasome. Trends Mol Med. 2015; 21(3): 193-201. PubMed Abstract | Publisher Full Text | Free Full Text

18. Bronner DN, Abuaita BH, Chen X, et al:: Endoplasmic Reticulum Stress Activates the Inflammasome via NLRP3- and Caspase-2-Driven Mitochondrial Damage. Immunity. 2015; 43(3): 451-62. PubMed Abstract | Publisher Full Text | Free Full Text

19. Lerner AG, Upton JP, Praveen PV, et al.: IRE1 $\alpha$ induces thioredoxin-interacting protein to activate the NLRP 3 inflammasome and promote programmed cell death under irremediable ER stress. Cell Metab. 2012; 16(2): 250-64. PubMed Abstract | Publisher Full Text | Free Full Text

20. F Zhang Z, Meszaros G, He WT, et al:: Protein kinase D at the Golgi controls NLRP3 inflammasome activation. J Exp Med. 2017; 214(9): 2671-93. PubMed Abstract | Publisher Full Text | Free Full Text | F1000 Recommendation

21. de La Roche M, Hamilton C, Mortensen R, et al:: Trafficking of cholesterol to the ER is required for NLRP3 inflammasome activation. J Cell Biol. 2018; 217(10): 3560-76.

PubMed Abstract | Publisher Full Text | Free Full Text

22. F Chen J, Chen ZJ: Ptdlns4P on dispersed trans-Golgi network mediates NLRP3 inflammasome activation. Nature. 2018; 564(7734): 71-6. PubMed Abstract| Publisher Full Text |F1000 Recommendation

23. F Campden RI, Zhang Y: The role of lysosomal cysteine cathepsins in NLRP3 inflammasome activation. Arch Biochem Biophys. 2019; pii: S00039861(18)30811-7.

PubMed Abstract | Publisher Full Text | F1000 Recommendation

24. Hornung V, Latz E: Critical functions of priming and lysosomal damage for NLRP3 activation. Eur J Immunol. 2010; 40(3):620-3. PubMed Abstract | Publisher Full Text | Free Full Text

25. He Y, Hara H, Núñez G: Mechanism and Regulation of NLRP3 Inflammasome Activation. Trends Biochem Sci. 2016; 41(12): 1012-21. PubMed Abstract | Publisher Full Text | Free Full Text

26. F Zhou R, Yazdi AS, Menu P, et al:: A role for mitochondria in NLRP3 inflammasome activation. Nature. 2011; 469(7329): 221-5. PubMed Abstract | Publisher Full Text | F1000 Recommendation

27. Yang CS, Kim JJ, Kim TS, et al.: Small heterodimer partner interacts with NLRP3 and negatively regulates activation of the NLRP3 inflammasome. Nat Commun 2015; 6: 6115.

PubMed Abstract | Publisher Full Text | Free Full Text

28. Wang $\mathrm{Y}$, Yang $\mathrm{C}$, Mao $\mathrm{K}$, et al.: Cellular localization of NLRP3 inflammasome. Protein Cell. 2013; 4(6): 425-31.

PubMed Abstract | Publisher Full Text | Free Full Text

29. F Bruchard M, Rebé C, Derangère V, et al:: The receptor NLRP3 is a transcriptional regulator of $\mathrm{T}_{\mathbf{H}} 2$ differentiation. Nat Immunol. 2015; 16(8): 859-70. PubMed Abstract | Publisher Full Text | F1000 Recommendation

30. Subramanian N, Natarajan K, Clatworthy MR, et al: The adaptor MAVS promotes
NLRP3 mitochondrial localization and inflammasome activation. Cell. 2013 153(2): 348-61.

PubMed Abstract | Publisher Full Text | Free Full Text

31. F Seth RB, Sun L, Ea CK, et al:: Identification and characterization of MAVS mitochondrial antiviral signaling protein that activates NF-kappaB and IRF 3 . Cell. 2005; 122(5): 669-82.

PubMed Abstract | Publisher Full Text | F1000 Recommendation

32. Park S, Juliana C, Hong S, et al:: The mitochondrial antiviral protein MAVS associates with NLRP3 and regulates its inflammasome activity. $J$ Immunol. 2013; 191(8): 4358-66.

PubMed Abstract | Publisher Full Text | Free Full Text

33. F Li X, Thome S, Ma X, et al.: MARK4 regulates NLRP3 positioning and inflammasome activation through a microtubule-dependent mechanism. Nat Commun. 2017; 8: 15986

PubMed Abstract | Publisher Full Text | Free Full Text | F1000 Recommendation

34. $\mathrm{F}$ Misawa T, Takahama M, Kozaki T, et al:: Microtubule-driven spatial arrangement of mitochondria promotes activation of the NLRP3 inflammasome. Nat Immunol. 2013; 14(5): 454-60.

PubMed Abstract | Publisher Full Text | F1000 Recommendation

35. Sagulenko V, Thygesen SJ, Sester DP, et al.: AIM2 and NLRP3 inflammasomes activate both apoptotic and pyroptotic death pathways via ASC. Cell Death Differ. 2013; 20(9): 1149-60.

PubMed Abstract | Publisher Full Text | Free Full Tex

36. F Shimada K, Crother TR, Karlin J, et al:: Oxidized mitochondrial DNA activates the NLRP3 inflammasome during apoptosis. Immunity. 2012; 36(3): 401-14.

PubMed Abstract | Publisher Full Text | Free Full Text | F1000 Recommendation

37. lyer SS, He Q, Janczy JR, et al.: Mitochondrial cardiolipin is required for NIrp3 inflammasome activation. Immunity. 2013; 39(2): 311-23.

PubMed Abstract | Publisher Full Text | Free Full Text

38. Cruz $\mathrm{CM}$, Rinna $\mathrm{A}$, Forman $\mathrm{HJ}$, et al.: ATP activates a reactive oxygen speciesdependent oxidative stress response and secretion of proinflammatory cytokines in macrophages. J. Biol. Chem. 2007; 282(5): 2871-9. PubMed Abstract | Publisher Full Text | Free Full Text

39. F Dostert C, Pétrilli V, Van Bruggen R, et al:: Innate immune activation through Nalp3 inflammasome sensing of asbestos and silica. Science. 2008; 320(5876): 674-7

PubMed Abstract | Publisher Full Text | Free Full Text | F1000 Recommendation

40. Wu J, Yan Z, Schwartz DE, et al.: Activation of NLRP3 inflammasome in alveolar macrophages contributes to mechanical stretch-induced lung inflammation and injury. J Immunol. 2013; 190(7): 3590-9.

PubMed Abstract | Publisher Full Text | Free Full Text

41. $\mathrm{F}$ Yu J, Nagasu $\mathrm{H}$, Murakami $\mathrm{T}$, et al:: Inflammasome activation leads to Caspase-1-dependent mitochondrial damage and block of mitophagy. Proc Natl Acad Sci U S A. 2014: 111(43): 15514-9.

PubMed Abstract | Publisher Full Text | Free Full Text | F1000 Recommendation

42. $\mathrm{F}$ Muñoz-Planillo $\mathrm{R}$, Kuffa $\mathrm{P}$, Martínez-Colón $\mathrm{G}$, et al:: $\mathbf{K}^{+}$efflux is the common trigger of NLRP3 inflammasome activation by bacterial toxins and particulate matter. Immunity. 2013; 38(6): 1142-53.

PubMed Abstract | Publisher Full Text | Free Full Text | F1000 Recommendation

43. Mohamed IN, Hafez SS, Fairaq A, et al.: Thioredoxin-interacting protein is required for endothelial NLRP3 inflammasome activation and cell death in a rat model of high-fat diet. Diabetologia. 2014; 57(2): 413-23. PubMed Abstract | Publisher Full Text | Free Full Text

44. El-Azab MF, Baldowski BRB, Mysona BA, et al: Deletion of thioredoxininteracting protein preserves retinal neuronal function by preventing inflammation and vascular injury. Br J Pharmacol. 2014; 171(5): 1299-313. PubMed Abstract | Publisher Full Text | Free Full Text

45. F Chen W, Zhao M, Zhao S, et al:: Activation of the TXNIP/NLRP3 inflammasome pathway contributes to inflammation in diabetic retinopathy: a novel inhibitory effect of minocycline. Inflamm Res. 2017; 66(2): 157-66. PubMed Abstract | Publisher Full Text | F1000 Recommendation

46. F Zhou R, Tardivel A, Thorens B, et al:: Thioredoxin-interacting protein links oxidative stress to inflammasome activation. Nat Immunol. 2010; 11(2): 136-40. PubMed Abstract | Publisher Full Text | F1000 Recommendation

47. F Cordero MD, Alcocer-Gómez E, Marín-Aguilar F, et al:: Mutation in cytochrome $b$ gene of mitochondrial DNA in a family with fibromyalgia is associated with NLRP3-inflammasome activation. J Med Genet. 2016; 53(2): $113-22$.

PubMed Abstract | Publisher Full Text | F1000 Recommendation

48. Tassi S, Carta S, Delfino L, et al.: Altered redox state of monocytes from cryopyrin-associated periodic syndromes causes accelerated IL-1beta secretion. Proc Natl Acad Sci U S A. 2010; 107(21): 9789-94. PubMed Abstract | Publisher Full Text | Free Full Text

49. F Bulua AC, Simon A, Maddipati R, et al:: Mitochondrial reactive oxygen species promote production of proinflammatory cytokines and are elevated in TNFR1-associated periodic syndrome (TRAPS). J Exp Med. 2011; 208(3): 519-33.

PubMed Abstract | Publisher Full Text | Free Full Text | F1000 Recommendation

50. F Nakahira K, Haspel JA, Rathinam VA, et al.: Autophagy proteins regulate 
innate immune responses by inhibiting the release of mitochondrial DNA mediated by the NALP3 inflammasome. Nat Immunol. 2011; 12(3): 222-30. PubMed Abstract | Publisher Full Text | Free Full Text | F1000 Recommendation

51. Coll RC, Holley CL, Schroder K: Mitochondrial DNA synthesis fuels NLRP3 inflammasome. Cell Res. 2018; 28(11): 1046-7. PubMed Abstract | Publisher Full Text | Free Full Text

52. F West AP, Brodsky IE, Rahner C, et al:: TLR signalling augments macrophage bactericidal activity through mitochondrial ROS. Nature. 2011; 472(7344): 476-80.

PubMed Abstract | Publisher Full Text | Free Full Text | F1000 Recommendation

53. F Zhong Z, Liang S, Sanchez-Lopez E, et al.: New mitochondrial DNA synthesis enables NLRP3 inflammasome activation. Nature. 2018; 560(7717): 198-203.

PubMed Abstract | Publisher Full Text | Free Full Text | F1000 Recommendation

54. F Carlos D, Costa FR, Pereira CA, et al:: Mitochondrial DNA Activates the NLRP3 Inflammasome and Predisposes to Type 1 Diabetes in Murine Model. Front Immunol. 2017; 8: 164

PubMed Abstract | Publisher Full Text | Free Full Text | F1000 Recommendation

55. F Szeto HH, Liu S, Soong Y, et al:: Mitochondria Protection after Acute Ischemia Prevents Prolonged Upregulation of IL-1 $\beta$ and IL-18 and Arrests CKD. J Am Soc Nephrol. 2017; 28(5): 1437-49.

PubMed Abstract | Publisher Full Text | Free Full Text | F1000 Recommendation

56. F Tumurkhuu G, Shimada K, Dagvadorj J, et al:: Ogg1-Dependent DNA Repair Regulates NLRP3 Inflammasome and Prevents Atherosclerosis. Circ Res. 2016; 119(6): e76-90.

PubMed Abstract | Publisher Full Text | F1000 Recommendation

57. Lu B, Kwan K, Levine YA, et al.: $\alpha \mathbf{7}$ nicotinic acetylcholine receptor signaling inhibits inflammasome activation by preventing mitochondrial DNA release. Mol Med. 2014; 20: 350-8.

PubMed Abstract | Publisher Full Text | Free Full Text

58. F Liu X, Zhou W, Zhang X, et al.: Dimethyl fumarate ameliorates dextran sulfate sodium-induced murine experimental colitis by activating Nrf2 and suppressing NLRP3 inflammasome activation. Biochem Pharmacol. 2016; 112 37-49.

PubMed Abstract | Publisher Full Text | F1000 Recommendation

59. Yao X, Carlson D, Sun Y, et al:: Mitochondrial ROS Induces Cardiac Inflammation via a Pathway through mtDNA Damage in a Pneumonia-Related Sepsis Model. PLoS One. 2015; 10(10): e0139416. PubMed Abstract | Publisher Full Text | Free Full Text

60. F Lupfer C, Thomas PG, Anand PK, et al.: Receptor interacting protein kinase 2-mediated mitophagy regulates inflammasome activation during virus infection. Nat Immunol. 2013; 14(5): 480-8.

PubMed Abstract | Publisher Full Text | Free Full Text | F1000 Recommendation

61. F Zhong Z, Umemura A, Sanchez-Lopez E, et al:: NF-кB Restricts Inflammasome Activation via Elimination of Damaged Mitochondria. Cell. 2016; 164(5): 896-910.

PubMed Abstract | Publisher Full Text | Free Full Text | F1000 Recommendation

62. Jabir MS, Hopkins L, Ritchie ND, et al:: Mitochondrial damage contributes to Pseudomonas aeruginosa activation of the inflammasome and is downregulated by autophagy. Autophagy. 2014; 11(1): 166-82. PubMed Abstract | Publisher Full Text | Free Full Text

63. Sutterwala FS, Mijares LA, Li L, et al.: Immune recognition of Pseudomonas aeruginosa mediated by the IPAF/NLRC4 inflammasome. J Exp Med. 2007; 204(13): 3235-45.

PubMed Abstract | Publisher Full Text | Free Full Text

64. F Dang EV, McDonald JG, Russell DW, et al:: Oxysterol Restraint of Cholesterol Synthesis Prevents AIM2 Inflammasome Activation. Cell. 2017; 171(5): 1057-1071.e11.

PubMed Abstract | Publisher Full Text | Free Full Text | F1000 Recommendation

65. Lupfer CR, Rippee-Brooks MD, Anand PK: Common Differences: The Ability of Inflammasomes to Distinguish Between Self and Pathogen Nucleic Acids During Infection. Int Rev Cell Mol Biol. 2019; 344: 139-72. PubMed Abstract | Publisher Full Text

66. Shi CS, Kehrl JH: Cytochrome c Negatively Regulates NLRP3 Inflammasomes. PLoS One. 2016; 11(12): e0167636.

PubMed Abstract | Publisher Full Text | Free Full Text

67. F Elliott EI, Miller AN, Banoth B, et al:: Cutting Edge: Mitochondrial Assembly of the NLRP3 Inflammasome Complex Is Initiated at Priming. J Immunol. 2018 200(9): 3047-52

PubMed Abstract | Publisher Full Text | Free Full Text | F1000 Recommendation

68. Mills EL, Kelly B, O'Neill LAJ: Mitochondria are the powerhouses of immunity. Nat Immunol. 2017; 18(5): 488-98. PubMed Abstract | Publisher Full Text

69. Bravo $R$, Parra V, Gatica $D$, et al:: Endoplasmic reticulum and the unfolded protein response: dynamics and metabolic integration. Int Rev Cell Mol Biol. 2013; 301: 215-90.

PubMed Abstract | Publisher Full Text | Free Full Text

70. Sano R, Reed JC: ER stress-induced cell death mechanisms. Biochim Biophys

Acta. 2013; 1833(12): 3460-70.

PubMed Abstract | Publisher Full Text | Free Full Text
71. Chaudhari N, Talwar P, Parimisetty A, et al:: A molecular web: endoplasmic reticulum stress, inflammation, and oxidative stress. Front Cell Neurosci. 2014; 8: 213.

PubMed Abstract | Publisher Full Text | Free Full Text

72. Shenderov K, Riteau N, Yip R, et al:: Cutting edge: Endoplasmic reticulum stress licenses macrophages to produce mature IL-1 $\beta$ in response to TLR 4 stimulation through a caspase-8- and TRIF-dependent pathway. J Immunol. 2014; 192(5): 2029-33.

PubMed Abstract | Publisher Full Text | Free Full Text

73. Kim S, Joe $\mathrm{Y}$, Jeong SO, et al:: Endoplasmic reticulum stress is sufficient for the induction of IL-1 $\beta$ production via activation of the NF-KB and inflammasome pathways. Innate Immun. 2014; 20(8): 799-815. PubMed Abstract | Publisher Full Text

74. Menu P, Mayor A, Zhou R, et al:: ER stress activates the NLRP3 inflammasome via an UPR-independent pathway. Cell Death Dis. 2012; 3: e261. PubMed Abstract | Publisher Full Text | Free Full Text

75. F Chen D, Dixon BJ, Doycheva DM, et al.: IRE1 $\alpha$ inhibition decreased TXNIP/ NLRP3 inflammasome activation through miR-17-5p after neonatal hypoxicischemic brain injury in rats. $J$ Neuroinflammation. 2018; 15(1): 32. PubMed Abstract | Publisher Full Text | Free Full Text | F1000 Recommendation

76. F Tufanli O, Telkoparan Akillilar P, Acosta-Alvear D, et al.: Targeting IRE1 with small molecules counteracts progression of atherosclerosis. Proc Natl Acad Sci U S A. 2017; 114(8): E1395-E1404.

PubMed Abstract | Publisher Full Text | Free Full Text | F1000 Recommendation

77. Oslowski CM, Hara T, O'Sullivan-Murphy B, et al.: Thioredoxin-interacting protein mediates ER stress-induced $\beta$ cell death through initiation of the inflammasome. Cell Metab. 2012; 16(2): 265-73. PubMed Abstract | Publisher Full Text | Free Full Text

78. F Robblee MM, Kim CC, Porter Abate J, et al.: Saturated Fatty Acids Engage an IRE1 $\alpha$-Dependent Pathway to Activate the NLRP3 Inflammasome in Myeloid Cells. Cell Rep. 2016; 14(11): 2611-23.

PubMed Abstract | Publisher Full Text | Free Full Text | F1000 Recommendation

79. F Ando T, Komatsu T, Naiki Y, et al:: GSK2656157, a PERK inhibitor, reduced LPS-induced IL-1 $\beta$ production through inhibiting Caspase 1 activation in macrophage-like J774.1 cells. Immunopharmacol Immunotoxicol. 2016; 38(4) 298-302

PubMed Abstract | Publisher Full Text | F1000 Recommendation

80. F Han CY, Rho HS, Kim A, et al:: FXR Inhibits Endoplasmic Reticulum StressInduced NLRP3 Inflammasome in Hepatocytes and Ameliorates Liver Injury. Cell Rep. 2018; 24(11): 2985-99.

PubMed Abstract | Publisher Full Text | F1000 Recommendation

81. F Guo M, Wang $X$, Zhao $Y$, et al.: Ketogenic Diet Improves Brain Ischemic Tolerance and Inhibits NLRP3 Inflammasome Activation by Preventing Drp1Mediated Mitochondrial Fission and Endoplasmic Reticulum Stress. Front Mo Neurosci. 2018; 11: 86

PubMed Abstract | Publisher Full Text | Free Full Text | F1000 Recommendation

82. F Lebeaupin C, Vallée D, Rousseau $D$, et al:: Bax inhibitor-1 protects from nonalcoholic steatohepatitis by limiting inositol-requiring enzyme 1 alpha signaling in mice. Hepatology. 2018; 68(2): 515-32. PubMed Abstract | Publisher Full Text | F1000 Recommendation

83. F $\mathrm{Fu} \mathrm{X,} \mathrm{Li} \mathrm{D,} \mathrm{Wang} \mathrm{J,} \mathrm{et} \mathrm{al.:} \mathrm{Melatonin} \mathrm{inhibits} \mathrm{endoplasmic} \mathrm{reticulum} \mathrm{stress-}$ associated TXNIP/NLRP3 inflammasome activation in lipopolysaccharideinduced endometritis in mice. Int Immunopharmacol. 2018; 64: 101-9. PubMed Abstract | Publisher Full Text | F1000 Recommendation

84. F Li A, Zhang S, Li J, et al:: Metformin and resveratrol inhibit Drp1-mediated mitochondrial fission and prevent ER stress-associated NLRP3 inflammasome activation in the adipose tissue of diabetic mice. Mol Cell Endocrinol. 2016; 434: 36-47.

PubMed Abstract | Publisher Full Text | F1000 Recommendation

85. Lebeaupin $\mathrm{C}$, Proics $\mathrm{E}$, de Bieville $\mathrm{CH}$, et al:: ER stress induces NLRP3 inflammasome activation and hepatocyte death. Cell Death Dis. 2015; 6: e1879. PubMed Abstract | Publisher Full Text | Free Full Text

86. D'Osualdo A, Anania VG, Yu K, et al.: Transcription Factor ATF4 Induces NLRP1 Inflammasome Expression during Endoplasmic Reticulum Stress. PLOS One. 2015; 10(6): e0130635

PubMed Abstract | Publisher Full Text | Free Full Text

87. F Xu Z, Wang H, Wei S, et al.: Inhibition of ER stress-related IRE1 $\alpha / C R E B /$ NLRP1 pathway promotes the apoptosis of human chronic myelogenous leukemia cell. Mol Immunol. 2018; 101: 377-85. PubMed Abstract | Publisher Full Text | F1000 Recommendation

88. F Cao L, Chen Y, Zhang Z, et al.: Endoplasmic Reticulum Stress-Induced NLRP1 Inflammasome Activation Contributes to Myocardial Ischemia/ Reperfusion Injury. Shock. 2019; 51(4): 511-8. PubMed Abstract | Publisher Full Text | F1000 Recommendation

89. Murakami T, Ockinger $\mathrm{J}$, Yu J, et al:: Critical role for calcium mobilization in activation of the NLRP3 inflammasome. Proc Natl Acad Sci U S A. 2012; 109(28): $11282-7$.

PubMed Abstract | Publisher Full Text | Free Full Text

90. F Lee GS, Subramanian N, Kim Al, et al:: The calcium-sensing receptor regulates the NLRP3 inflammasome through $\mathrm{Ca}^{2+}$ and cAMP. Nature. 2012; 
492(7427): 123-7.

PubMed Abstract | Publisher Full Text | Free Full Text | F1000 Recommendation

91. F Katsnelson MA, Rucker LG, Russo HM, et al:: $\mathbf{K}^{+}$efflux agonists induce NLRP3 inflammasome activation independently of $\mathrm{Ca}^{2+}$ signaling. $J$ Immuno 2015; 194(8): 3937-52.

PubMed Abstract | Publisher Full Text | Free Full Text | F1000 Recommendation

92. F Guo C, Chi Z, Jiang D, et al:: Cholesterol Homeostatic Regulator SCAPSREBP2 Integrates NLRP3 Inflammasome Activation and Cholesterol Biosynthetic Signaling in Macrophages. Immunity. 2018; 49(5): 842-856.e7. PubMed Abstract | Publisher Full Text | F1000 Recommendation

93. F Jang J, Park S, Jin Hur H, et al.: 25-hydroxycholesterol contributes to cerebral inflammation of $\mathrm{X}$-linked adrenoleukodystrophy through activation of the NLRP3 inflammasome. Nat Commun. 2016; 7: 13129

PubMed Abstract | Publisher Full Text | Free Full Text | F1000 Recommendation
94. F Hong S, Hwang I, Gim E, et al:: Brefeldin A-sensitive ER-Golgi vesicle trafficking contributes to NLRP3-dependent caspase-1 activation. FASEB 2019; 33(3): 4547-58.

PubMed Abstract | Publisher Full Text | F1000 Recommendation by phosphorylation of the pyrin domain. J Exp Med. 2017; 214(6): 1725-36.

PubMed Abstract | Publisher Full Text | Free Full Text | F1000 Recommendation

96. F Spalinger MR, Kasper S, Gottier C, et al.: NLRP3 tyrosine phosphorylation is controlled by protein tyrosine phosphatase PTPN22. J Clin Invest. 2016; 126(5): 1783-800.

PubMed Abstract | Publisher Full Text | Free Full Text | F1000 Recommendation

97. Brown MS, Goldstein JL: Cholesterol feedback: from Schoenheimer's bottle to Scap's MELADL. J Lipid Res. 2009; 50 Suppl: S15-27.

PubMed Abstract | Publisher Full Text | Free Full Text 


\section{Open Peer Review}

\section{Current Peer Review Status:}

\section{Editorial Note on the Review Process}

Faculty Reviews are review articles written by the prestigious Members of Faculty Opinions. The articles are commissioned and peer reviewed before publication to ensure that the final, published version is comprehensive and accessible. The reviewers who approved the final version are listed with their names and affiliations.

\section{The reviewers who approved this article are:}

\section{Version 1}

\section{Masafumi Takahashi}

Division of Inflammation Research, Center for Molecular Medicine, Jichi Medical University, Tochigi, Japan Competing Interests: No competing interests were disclosed.

\section{Je-Wook Yu} Department of Microbiology and Immunology, Yonsei University College of Medicine, Seoul, South Korea

Competing Interests: No competing interests were disclosed.

\section{Rongbin Zhou}

Institute of Immunology, School of Life Science, University of Science and Technology of China, Hefei, China

Competing Interests: No competing interests were disclosed.

The benefits of publishing with F1000Research:

- Your article is published within days, with no editorial bias

- You can publish traditional articles, null/negative results, case reports, data notes and more

- The peer review process is transparent and collaborative

- Your article is indexed in PubMed after passing peer review

- Dedicated customer support at every stage

For pre-submission enquiries, contact research@f1000.com 